\title{
Energy saving measures to improve the microclimate in poultry facilities
}

\author{
Nadiia Spodyniuk ${ }^{1}$, Oksana Pshenychna ${ }^{2}$
}

ABSTRACT:

The provision of a microclimate for poultry houses with the help of radiant heating systems has become widespread. Infrared heating systems, unlike other systems for providing the microclimate of poultry houses, provide local heating. When placed correctly, infrared heaters heat only the area where the poultry is located. When using infrared heaters, it is possible to achieve the necessary conditions in the location of the poultry, without increasing the temperature of the indoor air, and if possible, reducing it. Studies were conducted on a system that combined an infrared emitter for local heating and an exhaust umbrella to remove gaseous harmful substances from the up-per part of the poultry's location. From the results of the experiment and the obtained graphical and analytical dependences, the optimum air temperature in the poultry's location was determined.

\section{KEYWORDS}

infrared heating; poultry's location; thermal performance of the heater

\section{Introduction}

At present, the provision of a microclimate for poultry houses with the help of radiant heating systems has become widespread. Infrared heating systems, unlike other systems for providing the microclimate in poultry houses, provide local heating. When placed correctly, infrared heaters heat only the area where the poultry is located. This eliminates the need to heat the entire room. This is the economic effect of using infrared heaters. When using infrared heaters, it is pos-sible to achieve the necessary conditions in the location of the poultry, without increasing the temperature of the indoor air, and if possible, reducing it. This again proves the economic feasibility of using infrared heaters.

Figure 1 shows gas infrared heaters "TERMOBILE" and "SIERRA" [1-3]. They can be used as additional heating means to the existing heating system in the poultry house. Infrared gas emitters of this type run on natural or liquefied gas. As a result, there is no need to heat the entire poultry house to achieve the required temperature in the poultry location. The floor of the poultry house is constantly exposed to infrared rays and remains dry, unlike the use of other heating systems. Thus there is an energy saving from 30 to 50\% [4].

Analysis of existing studies has shown that it is advisable to place above the infrared heater an outlet exhaust umbrella. It performs the function of localizing harmful contaminants in the upper zone under the infrared heater (Fig. 2) [5].

As can be seen from Figure 2, the heated production room, which includes the poultry house, is divided into two zones in height. The air in the upper zone receives additional convective thermal energy from infrared emitters. In the lower zone there are convective flows over the heated floor surface. These heat fluxes rise to the upper zone. Thus, the heat entering the upper zone does not participate in ensuring the thermal regime of the working area and contains contaminants, which should be localized by the exhaust umbrella.

${ }^{1}$ National University of Life and Environmental Sciences of Ukraine, lecturer, orcid id: 0000-0002-2865-9320

2 National University of Life and Environmental Sciences of Ukraine, lecturer, orcid id: 0000-0002-9794-5822 
a)

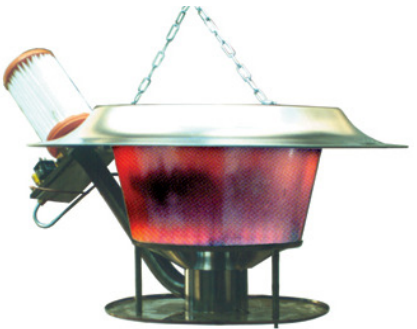

b)

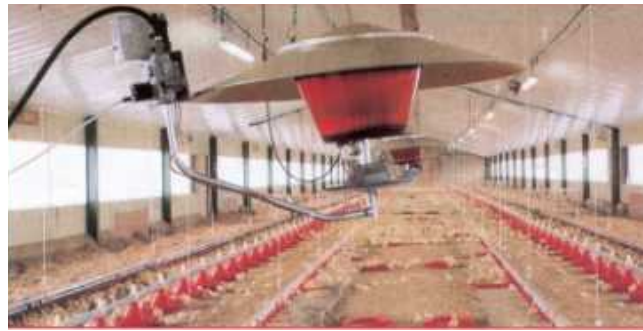

Fig. 1. Gas infrared heaters "TERMOBILE” (a), and "SIERRA" (b) [3]

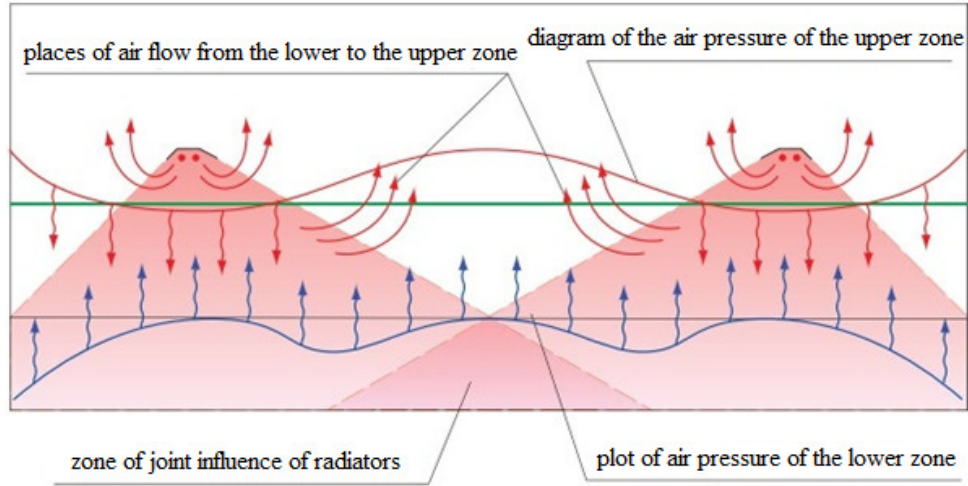

Fig. 2. Aerodynamic model of a premises heated by infrared emitters [5]

\section{Experimental studies}

Studies were conducted on a system that combined an infrared emitter for local heating and an exhaust umbrella to remove gaseous harmful substances from the upper part of the poultry's location. The versatility of this design lies in the combination of a local exhaust ventilation system with an infrared heating system (Fig. 3) [6].

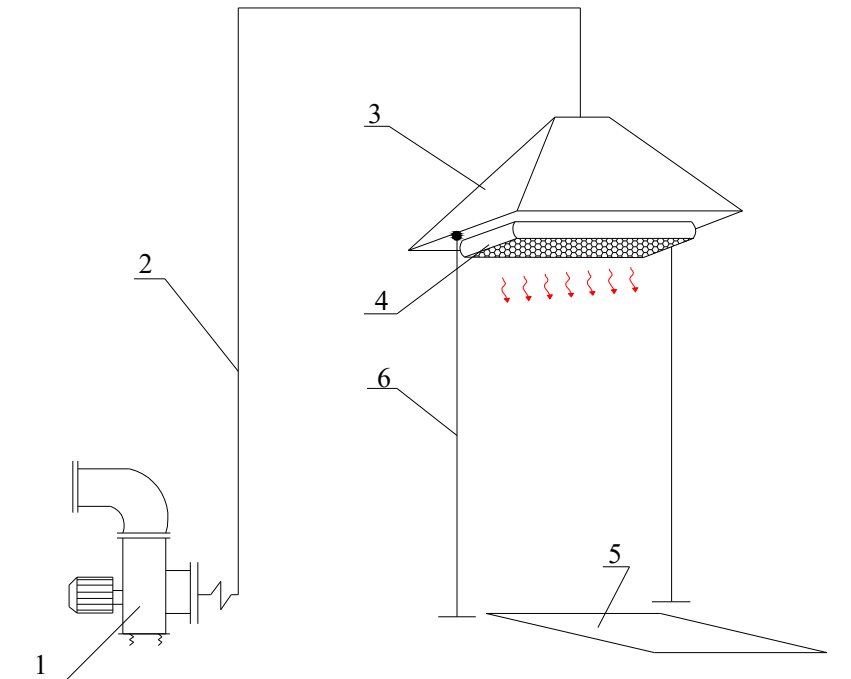

Fig. 3. The experimental setup [6]: 1 - fan; 2 - air duct; 3 - exhaust umbrella; 4 - infrared heater; 5 - irradiation surface; 6 - tripod 
Consider one of the stages of research, namely the study of air temperature during infrared heating and the influence of major factors on it.

Experimental studies of air temperature during infrared heating have shown that its value is influenced by the thermal performance of the heater $(Q, \mathrm{~W})$, the height of its installation $(H, \mathrm{~m})$ and the degree of blackness of the heating surface $(\varepsilon)$. These values were the input parameters of the experiment. The initial parameter is the relative temperature of the indoor air, $\bar{t}_{\text {in }}=\frac{t_{\mathrm{e}}}{t_{\mathrm{b}}}$, namely the ratio of the indoor air temperature in the poultry's location (experimental) $t_{\mathrm{e}},{ }^{\circ} \mathrm{C}$ to the background indoor air temperature $t_{\mathrm{b}},{ }^{\circ} \mathrm{C}$.

To study the indoor air temperature, a regression equation was obtained:

$$
y=1.2+0.07 x_{1}+0.09 x_{2}+0.15 x_{3}+0.02 x_{1} x_{2}+0.05 x_{1} x_{3}+0.12 x_{2} x_{3}+0.05 x_{1} x_{2} x_{3}
$$

As a result of the equation to determine the relative temperature of the indoor air, $\bar{t}_{\text {in }}$ at $400 \mathrm{~W} \leq Q \leq 1200 \mathrm{~W}, 1.28 \mathrm{~m} \leq H \leq 1.72 \mathrm{~m}$ and $0.15 \leq \varepsilon \leq 0.92$ will take the form [7]:

$$
\begin{aligned}
& \bar{t}_{\text {in }}=1.2+0.07 \frac{Q-800}{400}+0.09 \frac{H-1.5}{0.22}+0.15 \frac{\varepsilon-0.535}{0.385}+0.02 \frac{Q-800}{400} \cdot \frac{H-1.5}{0.22}+ \\
& +0.05 \frac{Q-800}{400} \cdot \frac{\varepsilon-0.535}{0.385}+0.12 \frac{H-1.5}{0.22} \cdot \frac{\varepsilon-0.535}{0.385}+0.05 \frac{Q-800}{400} \cdot \frac{H-1.5}{0.22} \cdot \frac{\varepsilon-0.535}{0.385}
\end{aligned}
$$

For convenience in the use of results of the experimental studies, the three-factor nomogram of the dependence of the relative temperature of the indoor air on the thermal performance of the heater $(Q, W)$, the height of its installation $(H, m)$ and the degree of blackness of the heating surface $(\varepsilon)$ was constructed (Fig. 3).

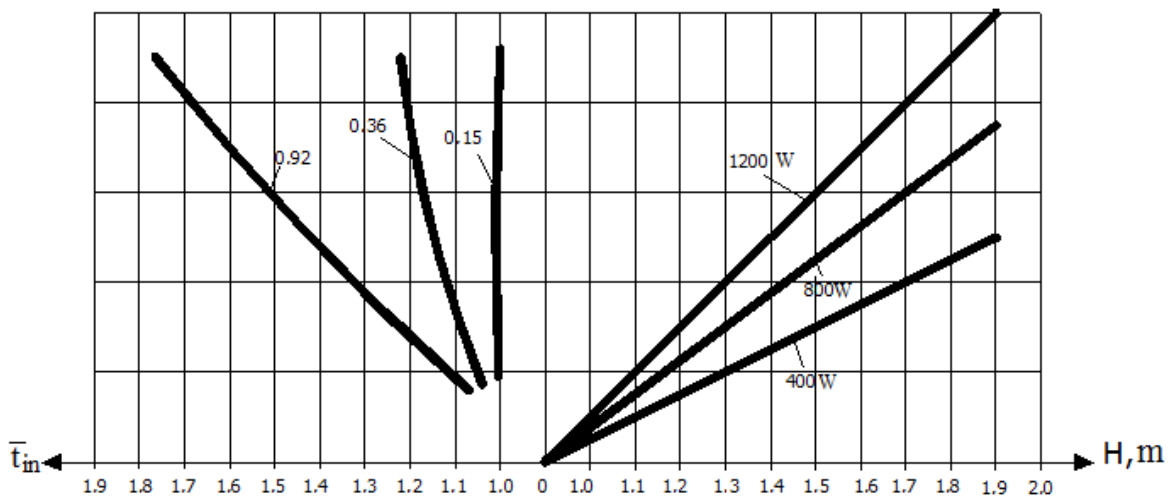

Fig. 4. Three-factor nomogram of dependence $\overline{t_{\text {in }}}=f(Q, H, \varepsilon)$ (own research)

\section{Conclusions}

The results of the experiment and the obtained graphical and analytical dependences allows the determination of the air temperature in the poultry's location. At the same time it is possible to observe the dependence of the temperature of the internal air on the thermal power of a heater, height of its installation and character of an underlying surface. 


\section{References}

[1] Bakowski K., Sieci i instalacje gazowe. Warszawa, Wydawnictwa Naukowo-Techniczne, 2002.

[2] Brown K.J., Farrelly R., O'shaughnessy S.M., Robinson A.J., Energy efficiency of electrical infra-red heating elements. Applied Energy 2016, 162, 581-588.

[3] Spodyniuk N., Kapalo P., Energicky efektívne systémy infračerveného vykurovania s utilizáciou tepla, Plynár vodár, kúrenár, klimatizácia. “V.O.Č SLOVAKIA, s.r.o.”, Košice 2010, 8(3), 27-29.

[4] Fedorov P.V., Heat application in agriculture. All-Union Agricultural Institute of Distance Education, 1975, 64.

[5] Shepitchak V., Savchenko O., Spodyniuk N., Zhelykh V., The study of temperature fields in exposure zone of the rotary infrared heaters. Budownictwo o Zoptymalizowanym Potencjale Energetycznym 2015, 1(15), 178-181.

[6] Yurkevich Yu., Spodyniuk N., Energy-saving infrared heating systems in industrial premises. Budownictwo o Zoptymalizowanym Potencjale Energetycznym 2015, 2(16), 140-144.

[7] Zhelykh V., Ulewicz M., Spodyniuk N., Shapoval S., Shepitchak V., Analysis of the processes of heat exchange on infrared heater surface, Diagnostyka 2016, 17(3), 81-85

\section{Oszczędność energii w celu poprawy mikroklimatu w obiektach drobiarskich}

\section{STRESZCZENIE:}

Zapewnienie mikroklimatu dla kurników za pomocą systemów ogrzewania promiennikowego stało się powszechne. Systemy ogrzewania na podczerwień, w przeciwieństwie do innych systemów zapewniających mikroklimat kurników, zapewniają lokalne ogrzewanie. Przy prawidłowym umieszczeniu promienniki podczerwieni ogrzewają tylko obszar, w którym znajduje się drób. Stosując promienniki na podczerwień, możliwe jest osiągnięcie niezbędnych warunków w lokalizacji drobiu, bez zwiększania temperatury powietrza w pomieszczeniu, a jeśli to możliwe, jej obniżania. Przeprowadzono badania nad systemem, który łączył promiennik podczerwieni do lokalnego ogrzewania i parasol wyciągowy w celu usunięcia szkodliwych substancji gazowych z górnej części stanowiska drobiu. Na podstawie wyników doświadczenia oraz uzyskanych zależności graficznych i analitycznych wyznaczono optymalną temperaturę powietrza w miejscu przebywania drobiu.

\section{SŁOWA KLUCZOWE:}

ogrzewanie na podczerwień; lokalizacja drobiu; wydajność cieplna nagrzewnicy 